\title{
VZDELÁVANIE DOSPELÝCH RÓMOV Z MARGINALIZOVANÝCH KOMUNÍT
}

PIROHOVÁ, I., LUKÁČ, M., LUKÁČOVÁ, S. 2019. Vzdelávanie dospelých Rómov z marginalizovaných komunit. Prešov: Vydavatelstvo Prešovskej univerzity v Prešove. 187 s. ISBN 978-80-555-2318-7.

Vzdelávanie dospelých je v každej modernej a uvedomelej spoločnosti primárnou prioritou rozvoja, o tom niet pochýb. Do popredia sa však konečne v oblasti edukácie dospelých dostáva aj zretel' na marginalizované sociálne skupiny, a to nie len v oblasti teoretickej, ale i výskumnej a praktickej. Monografická práca významných prešovských andragógov, docentky Ivany Pirohovej, doktora Mareka Lukáča a doktorky Silvie Lukáčovej, je toho dôkazom. Andragogická veda i prax edukácie dospelých nemôžu reflektovat len vzdelávanie ekonomicky stabilných skupín obyvatel'stva, práve naopak, je nevyhnutné zaoberat' sa sociálnymi skupinami, ktoré sú v spoločnosti ohrozené, marginalizované či vylúčené, skupinami, ktorých postavenie z vel'kej miery vyplýva aj z ich nízkeho socio-ekonomického a vzdelanostného statusu. A práve na takúto vzdelanostne „krehkú“ ciel'ovú skupinu edukácie, dospelých Rómov bez vzdelania alebo s nízkym vzdelaním, sa autori vo svojej monografickej práci zamerali.

Trojica autorov sa téme vzdelávania dospelých Rómov nevenuje prvýkrát-na svoje predošlé výskumné zistenia odkazuje na mnohých miestach novej monografie. Už v úvode autori vychádzajúc zo svojich výskumov upozorňujú, že redukovat' vzdelávanie Rómov z marginalizovaných komunít na školenia a tréningy pre trh práce, ako aj spôsob, akým sú vzdelávaní, nie sú účinné prostriedky integrácie tejto sociálnej skupiny do spoločenských štruktúr. Zároveň však nastavujú nielen praxi, ale aj andragogickej vede zrkadlo, ked' konštatujú, že slovenská andragogika doposial' nemá dostatočne rozpracovaný koncept marginalizácie - nevieme kto, za akých podmienok a prečo je považovaný za marginalizovaného učiaceho sa. Autori stanovujú kruciálnu otázku: akí vlastne sú marginalizovaní učiaci sa, v čom sú iní ako bežní učiaci sa dospelí a čo vlastne potrebujú? V slovenskej odbornej literatúre však na tieto otázky zatial' nejestvujú uspokojivé odpovede. Význam 
sociálneho pôvodu vo vzdelávaní dospelých je stále výskumne podceňovaný a prehliadaný. Tieto myšlienky možno považovat́ za akýsi hnací motor celej monografickej práce či tenkú červenú nit', ktorá sa tahá celou publikáciou - od teoretických východísk až po výskumné zistenia a ich interpretáciu.

Monografia má celkový rozsah 188 strán, pozostáva zo štyroch kapitol. Prvá kapitola je zameraná na teoretické východiská skúmanej problematiky. Autori v nej charakterizujú ciel'ovú skupinu dospelých Rómov z marginalizovaných komunít, primárne z edukačného, ale i sociologického hladiska, pričom vychádzajú najmä zo zahraničných zdrojov. Neopomínajú ani prizmy, cez ktoré možno na výskum tejto ciel'ovej skupiny nazerat', a zároveň charakterizujú i svoj prístup v skúmaní - edukáciu Rómov z marginalizovaných komunít nechápu ako prostriedok asimilácie, ale ako prostriedok sociálnej integrácie/inklúzie chudobných. Upozorňujú, že čast rómskej populácie je nositel'om vzorcov správania generačnej chudoby, čím dochádza aj k posilňovaniu etnickej chudoby. Aj vztah dospelých Rómov k škole a vzdelávaniu, ktorý sa vytváral už počas školskej dochádzky, sa prenáša generačne. Napriek tomu sa príčiny zlyhania inklúzie vo vzdelávaní spájajú s rómskou mentalitou, chudobou, a nie so systémom. Autori v prvej kapitole poukazujú aj na úskalia vo vzdelávaní dospelých Rómov. Jedným z nich je jazyk ako systém signálov, ktorým Rómovia nemusia prisudzovat rovnaké alebo podobné významy ako vzdelávatel. Ďalším je samotný ciel' vzdelávacích akcií, ktoré sú často projektované na základe potrieb a predstáv stredných sociálnych vrstiev. Inakost', ktorú treba brat' na zretel', môže byt' aj v ponímaní významu vzdelávania a vzdelania ako hodnoty. Rómska rodina je silne orientovaná na súčasnost', silné sú aj rodové stereotypizácie - muž zabezpečuje rodinu prácou, nepotrebuje sa dlho vzdelávat', žena sa stará o deti a manžela, môže sa vzdelávat', iba ak je slobodná a bezdetná. Autori však uvádzajú významnú predikciu, že v nasledujúcej generácii Rómov dôjde k zmene postojov ku škole i k d'alšiemu vzdelávaniu. Záver kapitoly je venovaný aj subjektu učitela a konceptu kultúrne citlivého vyučovania dospelých Rómov z marginalizovaných komunít. Autori uvádzajú, že facilitatívny spôsob vzdelávania dospelých Rómov je nepoužitel'ný. Učitel' musí byt schopný viest' s dospelými autentický dialóg, rešpektovat ich osobnost', byt prirodzenou autoritou a chápat Rómov v ich odlišnosti, pričom kultúrne citlivé vyučovanie vyžaduje od vzdelávatel'a dospelých odbornost', empatiu, entuziazmus, zrozumitel'nost a kultúrnu citlivost'.

Druhá kapitola je exkurzom do oblasti druhošancového vzdelávania dospelých. Autori sa venujú vymedzeniu samotného pojmu druhošancového 
vzdelávania dospelých, ako aj jeho inštitucionálnemu zabezpečeniu na základných a stredných odborných školách v podmienkach Slovenskej republiky, a aktuálnemu právnemu rámcu na získanie nižšieho stredného vzdelania a stredného odborného vzdelania. Zároveň kriticky analyzujú systém d'alšieho vzdelávania, ktorý nielen že neponúka alternatívu pre nevzdelaných a nezamestnaných, ale existujúce rozdiely ešte prehlbuje zvýrazňovaním kvalifikačných rozdielov. Navyše, na vzdelávaní dospelých sa zúčastňujú najmä tí, ktorí už vzdelaní sú, čím sa prehlbujú aj sociálne nerovnosti. Konštatujú, že v obsahu druhošancového vzdelávania dominujú odborné predmety na úkor predmetov výchovno-vzdelávacích. Skutočnost', že sa systém $\mathrm{k}$ rómskym detom z marginalizovaného prostredia správa nerovnako ako k detom z majoritnej spoločnosti, ovplyvňuje aj systém vzdelávania dospelých, ktorý nie je pripravený tieto nedostatky organizačne ani ideologicky kompenzovat. Systém vzdelávania musí vytvorit podmienky, v ktorých má každý bez rozdielu možnost' aktívne sa podielat' na utváraní vlastného života prostredníctvom aktualizácie vlastného vzdelanostného statusu v akejkolvek fáze života. Vzdelávanie podla autorov musí nadväzovat na uplatnenie sa na trhu práce, inak budú v praxi nad'alej prevažovat́ techniky negatívnej motivácie spočívajúce vo využívaní úradnej moci. K tomu však musí nastat i medzirezortná spolupráca.

Tretia kapitola je charakteristikou metodologických procedúr. Autori naznačujú, že o vzdelávaní dospelých Rómov je toho viac neznámeho, ako známeho. Hlavný ciel' výskumu zadefinovali ako pochopenie a interpretovanie hodnotenia druhošancového vzdelávania dospelými učiacimi sa Rómami, pričom stanovili výskumné otázky kategorizované do štyroch oblastí: motivácia, d'alej organizácia, obsah a priebeh vzdelávania, potom vztah učitel'ov a učiacich sa a napokon sociálne a ekonomické podmienky učenia sa v dospelosti. Výskum bol realizovaný kvalitatívnou metodológiou, konkrétne dizajnom zakotvenej teórie. Híbkové rozhovory prebiehali s desiatimi dospelými rómskymi ženami študujúcimi v trojročnom odbore krajčír a šiestimi dospelými mužmi a ženami študujúcimi odbor podnikanie $\mathrm{V}$ remeslách a službách $\mathrm{v}$ dvojročnom maturitnom štúdiu. Kapitola d'alej obsahuje transkripty zaradené do jednotlivých skúmaných kategórií, zavíšená je sekundárnou interpretáciou a kódovaním skúmaných javov. Zaujímavé výskumné zistenia priniesli, okrem iného, i to, že Rómovia chápu vzdelanie ako integrálnu súčast života vyšších sociálnych vrstiev, ako spôsob napíňania sociálnych potrieb, spolupatričnosti, kontaktov 
s pozitívnym vplyvom na ich sebavedomie. Vzdelávanie v dospelom veku považujú za náročnejšie ako to v detstve, cítia väčšiu zodpovednost'. Autori zistili, že stratégia vyrovnávania sa so školskými povinnostami závisí u Rómov od rodu, veku, rodinného stavu a úrovne i druhu podpory zo strany rodiny, pričom ako významné sa javí vzdelanie príbuzných a socio-ekonomické zázemie rodiny. Výskum poukázal aj na vplyv tretej osoby, Rómky, úspešnej ženy v komunite, ktorá dospelým učiacim sa rôznorodo pomáhala počas celého vzdelávacieho procesu, a bez ktorej intervencie by rómske ženy ani nezačali študovat'. Medzi d'alšie zaujímavé výskumné zistenia patrí, že ak výučba nenadväzuje na predchádzajúce vedomosti a zručnosti učiacich sa, nevytvoria si k predmetu vzțah a sú z neho neúspešní. Najoblúbenejšie sú predmety, ktoré sú uchopitel'né a pochopitel'né, bez potreby abstraktného myslenia. Negatívne sú prijímané výklady učitela spojené s diktovaním poznámok, naopak, pozitívne výučba s princípmi aktívneho učenia sa. Napriek tomu autori konštatujú, že vyučovanie malo charakter mechanického osvojovania si učiva, pričom problémové a dialogické metódy absentovali, čo nie je v súlade so známymi a dávno dobre popísanými zákonitostami učenia sa dospelých.

Posledná, štvrtá kapitola, ako aj záver monografie zhrňujú skúmané fenomény a navrhujú riešenia pre prax edukácie dospelých Rómov.

Monografiu docentky Pirohovej, doktora Lukáča a doktorky Lukáčovej možno bezpochyby považovat' za odborné dielo. Vzdelávanie dospelých Rómov z marginalizovaných komunít rozširuje diapazón vedeckovýskumných poznatkov andragogickej vedy, a som presvedčená, že zaujme nielen akademických pracovníkov z oblasti edukačných či iných príbuzných vied, ale aj odborníkov z praxe, ktorí s touto ciel'ovou skupinou pracujú.

\section{Autor recenze}

PhDr. Dominika Temiaková, PhD.

Univerzita Konštantína Filozofa v Nitre, Pedagogická fakulta, Katedra pedagogiky, Dražovská 4, Nitra, Slovenská republika

email: dtemiakova@ukf.sk

Přijato: 20. 2. 2020

Link to this article: https://doi.org/10.11118/lifele20201002257 